\title{
Evaluasi Program Penguatan Pendidikan Karakter Terintegrasi Mata Pelajaran Matematika di SMP Negeri
}

\author{
Elsy Senides Hana Taunu \\ Universitas Kristen Wira Wacana Sumba \\ elsysenides@gmail.com \\ Ade Iriani \\ Universitas Kristen Satya Wacana \\ ade.iriani@uksw.edu
}

\begin{abstract}
This study aims to determine the implementation, influence, and factors affecting the implementation of the program in SMP Negeri 2 Waingapu. This research type is evaluative research by using a qualitative method. The evaluation program model used is a goal-free evaluation model. Interviews, observations, and document studies are techniques used for data collection. Data validity test is done with triangulation, technique and data source triangulation. The results showed that 1) the implementation of character education program in SMP Negeri 2 Waingapu has not been optimal yet, either in terms of planning, implementation or evaluation; 2) the effect of the program on integrating character values in Mathematics is positive on student achievement and behavior but also negative on teacher workload; 3) factors which affect the program are: facilities and infrastructures, information access, teachers, students.
\end{abstract}

Keywords: Character Education Strengthening, Evaluation Program

\section{Article Info}

Received date: 6 Juni 2018

Revised date: 24 Juni 2019

Accepted date: 25 Juni 2019

\section{PENDAHULUAN}

Pendidikan adalah proses mengubah manusia menjadi lebih baik dalam pengetahuan, sikap dan keterampilan (Listyarti, 2012:4). Selain itu, pendidikan adalah proses pengubahan sikap dan tatalaku seseorang atau kelompok orang dalam usaha mendewasakan manusia melalui upaya pengajaran dan pelatihan, proses, cara, perbuatan mendidik (Pusat Bahasa Departemen Pendidikan Nasional. 2002 : 263), Sejalan dengan definisi tersebut, Sukmadinata (2004:1) juga mengemukan pendidikan sebagai upaya-upaya, yakni upaya mencerdaskan bangsa, menanamkan nilai-nilai moral dan agama, membina kepribadian, mengajarkan pengetahuan, melatih kecakapan, ketrampilan, memberikan bimbingan, arahan, tuntunan, teladan, dan lain-lain. Dengan demikian, pendidikan merupakan usaha sadar yang dilakukan secara terencana melalui kegiatan bimbingan, pengajaran, dan latihan, yang berlangsung di sekolah dan di luar sekolah untuk mengembangkan seluruh kemampuan (potensi) yang dimiliki seseorang baik itu pengetahuan, keterampilan dan sikap. Pendidikan tidak sebatas mentransfer ilmu pengetahuan, tetapi juga sekaligus 
sebagai proses alih nilai (Muslich, 2011: 47). Artinya bahwa pendidikan, dapat mengubah atau membentuk karakter dan watak seseorang agar menjadi lebih baik, lebih sopan dalam tataran etika maupun estetika maupun perilaku dalam kehidupan sehari-hari. Dalam kenyataannya, pendidikan di Indonesia belum mampu membentuk watak manusia menjadi lebih baik karena pada kenyataannya situasi dan kondisi karakter bangsa sangat memprihatinkan seperti maraknya tindakan intoleransi dan kekerasan yang mengatas namakan agama sehingga mengancam kebinekaan dan keutuhan NKRI, adanya gerakan-gerakan separatis, perilaku kekerasan di lingkungan pendidikan dan di masyarakat, kejahatan seksual, tawuran pelajar, pergaulan bebas dan kecenderungan anak-anak muda pada narkoba. Persoalan-persoalan tersebut dapat menjadi acaman bagi keutuhan, ketahanan dan masa depan bangsa, selain itu Indonesia juga menghadapi tantangan menghadapi persaingan global, seperti rendahnya indeks pembangunan manusia Indonesia mengancam daya saing bangsa, lemahnya fisik anak-anak Indonesia karena kurang olah raga, rendahnya rasa seni dan estetika serta pemahaman etika yang belum terbentuk selama masa pendidikan, peristiwaperistiwa yang menyimpang ini menunjukkan karakter generasi muda Indonesia sudah berada pada titik yang mengkhawatirkan sehingga mendorong pemerintah untuk mengambil inisiatif untuk memprioritaskan pembangunan karakter bangsa (Zubaedi, 2011:7; Kemendikbud 2017: 3-7;). sehingga pendidikan karakter sangat penting diterapkan demi mengembalikan karakter bangsa Indonesia yang sudah mulai luntur.

Melihat hal tersebut, banyak kalangan yang menilai bahwa saat ini bangsa Indonesia dalam kondisi sakit yang membutuhkan penanganan dan pengobatan secara tepat melalui pemberian pendidikan karakter disemua tingkatan pendidikan (Mulyasa, 2007:
17). Oleh karena itu Kementerian Pendidikan Nasional telah mencanangkan gerakan nasional berupa pendidikan karakter (20102025) melalui Keputusan Pemerintah Republik Indonesia pada tanggal 11 Mei 2010 tentang gerakan nasional pendidikan karakter berlandaskan Rencana Aksi Nasional (RAN) Pendidikan Karakter Bangsa. Hal tersebut perlu dilanjutkan, dioptimalkan, diperdalam, dan bahkan diperluas sehingga diperlukan penguatan pendidikan karakter bangsa. Untuk itu, sejak sekarang perlu dilaksanakan Gerakan Penguatan Pendidikan Karakter (PPK) dengan mengindahkan asas keberlanjutan dan kesinambungan rapuhnya karakter bangsa selama ini. Penguatan karakter bangsa menjadi salah satu butir Nawacita yang dicanangkan Presiden Joko Widodo melalui Gerakan Nasional Revolusi Mental (GNRM). Komitmen ini ditindaklanjuti dengan arahan Presiden kepada Menteri Pendidikan dan Kebudayaan untuk mengutamakan dan membudayakan pendidikan karakter di dalam dunia pendidikan. Atas dasar ini, Kementerian Pendidikan dan Kebudayaan mencanangkan Penguatan Pendidikan Karakter (PPK) secara bertahap mulai tahun 2016 (Kemendikbud, 2017:1).

PPK menempatkan pendidikan karakter sebagai dimensi terdalam atau inti pendidikan nasional sehingga pendidikan karakter menjadi poros pelaksanaan pendidikan dasar dan menengah. Lebih lanjut, gerakan PPK perlu mengintegrasikan, memperdalam, memperluas dan sekaligus menyelaraskan berbagai program dan kegiatan pendidikan karakter yang sudah dilaksanakan sampai sekarang. Dalam hubungan ini pengintegrasian dapat berupa pemanduan kegiatan kelas, luar kelas di sekolah dan luar sekolah (masyarakat/ komunitas); kegiatan intrakurikuler, kokurikuler dan ekstrakurikuler; pelibatan secara serempak warga sekolah, keluarga dan masyarakat; pendalaman dan perluasan dapat berupa penambahan dan pengintensifan 
kegiatan - kegiatan yang berorientasi pada pengembangan karakter siswa, penambahan dan pemajanan kegiatan belajar siswa dan pengaturan ulang waktu belajar siswa disekolah atau diluar sekolah; kemudian penyelarasan dapat berupa penyesuaian tugas pokok guru, manajemen berbasis sekolah dan fungsi komite sekolah dengan kebutuhan gerakan PPK (Kemendikbud, 2017: 5).

Pendidikan karakter adalah suatu proses pendidikan yang menekankan pada pengembangan dan pembentukan akhlak, watak, sifat baik atau positif pada diri peserta didik agar peserta didik paham, peduli dan bertindak berdasarkan nilai-nilai pendidikan karakter sehingga menjadikan peserta didik lebih baik. Pendidikan karakter di sekolah yang efektif dan utuh menyertakan tiga basis desain dalam pemogramannya. Tiga basis yang dimaksud adalah basis kelas, basis kultur sekolah dan basis komunitas (Albertus, 2012:105 - 153; Kemendikbud, 2017: 27 - 46; Muslich, 2011:90 - 91)

SMP Negeri 2 Waingapu merupakan salah satu sekolah negeri yang telah melaksanakan Program Penguatan Pendidikan Karakter. Berdasarkan hasil wawancara (Jumat, 01 September 2017) dengan salah seorang guru PPKN SMP Negeri 2 Waingapu Kabupaten Sumba Timur menyatakan pelaksanaan pendidikan karakter telah dilakukan oleh kepala sekolah, guru, tenaga kependidikan secara bersama-sama sebagai suatu komunitas pendidik dan diterapkan ke dalam kurikulum melalui: program pengembangan diri (kegiatan rutin sekolah, kegiatan spontan, keteladanan, dan pengkodisian), pengintegrasian dalam mata pelajaran, dan melalui budaya sekolah. Hal itu terlihat dari guru memberikan arahan tentang disiplin dan nilai - nilai karakter lainnya, doa bersama dan bersalaman baik antar siswa maupun guru, kegiatan Jumat bersih, dan kegiatan-kegiatan lain yang terintegrasi dalam pembelajaran. Apa yang dikatakan oleh kepala sekolah diperkuat dengan studi dokumen berupa data - data dan foto/gambar para siswa yang melaksanakan Program Penguatan Pendidikan Karakter. Melalui upaya ini maka pembelajaran dilatih keterampilan dasar, kemampuan intelektual serta nilai-nilai pendidikan karakter, sehingga dapat bersinergi, berkomunikasi, dan beradaptasi dalam masyarakat. Dalam hal ini guru harus memberikan kesempatan pada peserta didik untuk berpartisipasi aktif sehingga dapat membantu mengembangkan potensi serta kompetensi yang dimilikinya. Di sisi lain ternyata realitas di lapangan menunjukkan bahwa karakter dari siswa belum memenuhi pencapaian tujuan pendidikan karakter karena masih terdapat siswa yang tidak disiplin baik dalam hal waktu, bersikap dan mentaati peraturan seperti datang terlambat ke sekolah, tidak masuk sekolah tanpa izin, tidak memasukkan baju seragam, memakai seragam yang tidak sesuai dengan aturan berpakian yang ditetapkan sekolah, membuat keributan, tidak tertib, melawan bila ditegur, tidak ada rasa peduli terhadap lingkungan, dan lain sebagainya. Kepala sekolah juga mengungkapkan bahwa program pendidikan karakter yang telah dilaksanakan sekolah tersebut sampai saat ini belum pernah diadakan evaluasi. Berdasarkan keadaan yang demikian mendorong peneliti untuk mengkaji dan mengevaluasi tentang implementasi pendidikan karakter dalam pembelajaran di SMP Negeri 2 Waingapu dengan harapan pendidikan karakter telah diimplementasikan berdasarkan prinsip-prinsip dan ketentuan yang telah ditetapkan.

Persoalan serupa juga terjadi dibeberapa sekolah seperti penelitian yang dilakukan oleh Darmayanti dan Wibowo (2014) di sekolah dasar Kulon Progo, Nur Aisyah, Emosda, Suratno (2015) di SDIT Nurul Ilmi Kota Jambi dan Ekowati, Setyaningrum, dan Husamah (2012) di SD Muhammadiyah Kota Malang Ketiga 
penelitian tersebut menyatakan bahwa pendidikan karakter telah dilaksanakan berdasarkan ketentuan dan prinsip-prinsip implementasi meskipun masih terdapat beberapa kekurangan, seperti pelaksanaan yang hanya sekedar tuntutan administratif, kurangnya dukungan sarana dan prasarana, serta minimnya kesadaran guru dalam mengintegrasikan pendidikan karakter dalam pembelajaran.

Keberhasilan dari suatu program atau suatu kegiatan dapat diketahui dengan diadakannya evaluasi. Arikunto (2012:325) menyatakan bahwa Evaluasi program adalah rangkaian kegiatan yang dilakukan untuk melihat tingkat keberhasilan program. Melakukan evaluasi program adalah kegiatan untuk mengetahui seberapa tinggi tingkat keberhasilan dari kegiatan yang direncanakan. Tujuan diadakannya evaluasi program adalah untuk mengetahui pencapaian tujuan program dengan langkah mengetahui keterlaksanaan kegiatan program, karena evaluator program ini mengetahui bagaimana dari komponen dan sub komponen program yang belum terlaksana dan apa sebabnya. Oleh karena itu, sebelum melaksanakan evaluasi, evaluator perlu memperjelas tujuan program yang akan dievaluasi (Arikunto \& Jabar, 2010:18). Dalam evaluasi program, pelaksana (evaluator) ingin mengetahui tingkat ketercapaian program dan apabila tujuan belum tercapai pelaksana (evaluator) ingin mengetahui letak kekurangan dan sebabnya. Hasilnya digunakan untuk menentukan tindak lanjut atau keputusan yang akan diambil. Dalam kegiatan evaluasi program, indikator merupakan petunjuk untuk mengetahui keberhasilan atau ketidakberhasilan suatu kegiatan.

Salah satu model evaluasi yang cukup relevan yang dapat bagaimana kerjanya (kinerja) suatu program, dengan jalan mengidentifikasi penampilan-penampilan yang terjadi (pengaruh) baik hal-hal yang positif (yaitu hal yang diharapkan) maupun hal-hal yang negatif (yang tidak diharapkan) dalam Program Penguatan Pendidikan Karakter adalah model Goal Free yaitu model evaluasi yang dikembangkan oleh Michael Scriven. Model evaluasi ini merupakan model evaluasi mengenai pengaruh yang sesungguhnya, objektivitas yang ingin dicapai oleh program (Wirawan, 2011: 84), karena itu model tersebut dinilai cocok bagi program PPK yang baru diterapkan dalam proses pembelajaran pendidikan karakter, yang diharapkan program PPK memberi pengaruh dan dampak yang positif dalam kegiatan pembelajaran. Berdasarkan latar belakang di atas peneliti tertarik untuk mengadakan penelitian dengan judul "Evaluasi Program pendidikan Karakter Yang Terintegrasi Dalam Mata Pelajaran Matematika di SMP Negeri 2 Waingapu Kabupaten Sumba Timur"

Rumusan masalah dalam penelitian ini adalah Bagaimana implementasi program penguatan pendidikan karakter yang terintegrasi dalam mata pelajaran matematika di SMP Negeri 2 Waingapu Kabupaten Sumba Timur baik dalam perencanaan, pelaksanaan dan evaluasi? bagaimana pengaruh program penguatan pendidikan karakter yang terintegrasi dalam mata pelajaran matematika di SMP Negeri 2 Waingapu Kabupaten Sumba Timur? serta faktor - faktor apa saja yang terkait dengan program penguatan pendidikan karakter yang terintegrasi dalam mata pelajaran matematika di SMP Negeri 2 Waingapu Kabupaten Sumba Timur?

Tujuan penelitian ini dilakukan untuk mengetahui dan mengevaluasi Implementasi program penguatan pendidikan karakter yang terintegrasi dalam mata pelajaran matematika di SMP Negeri 2 Waingapu Kabupaten Sumba Timur baik dalam perencanaan, pelaksanaan dan evaluasi, pengaruh program serta faktor faktor yang terkait program penguatan pendidikan karakter di yang terintegrasi dalam 
mata pelajaran matematika di SMP Negeri 2 Waingapu Kabupaten Sumba Timur.

Keseluruhan dari hasil evaluasi ini akan digunakan untuk merekomendasikan perbaikan program pendidikan karakter khususnya kepada pihak sekolah.

\section{METODE PENELITIAN}

Penelitian ini merupakan penelitian evaluatif. Pendekatan yang digunakan dalam penelitian ini adalah pendekatan kualitatif. Penelitian ini akan di lakukan di SMP Negeri 2 Waingapu, Kabupaten Sumba Timur. Subyek penelitian adalah Kepala sekolah, guru mata pelajaran matematika berjumlah 3 orang dan 5 orang siswa. Waktu pelaksanaan penelitian adalah November-Desember 2017. Teknik pengumpulan data pada penelitian ini menggunakan studi dokumen, observasi, dan wawacara. Teknik analisis data yang digunakan adalah teknik analisis data kualitatif yang meliputi reduksi data, penyajian data, dan penarikan kesimpulan. Keabsahan data dalam penelitian ini menggunakan trianggulasi teknik dan triangulasi sumber.

\section{HASIL PENELITAN DAN \\ PEMBAHASAN}

\section{Hasil Penelitian}

\section{Implementasi Program}

Integrasi pendidikan karakter di dalam proses pembelajaran dilaksanakan mulai dari tahap perencanaan, pelaksanaan, dan penilaian pembelajaran. Pada perencanaan pembelajaran dirancang dalam bentuk silabus dan Rencana Pelaksanaan Pembelajaran (RPP) yang mengacu pada standar isi. Dalam silabus dan RPP terlihat bahwa nilai-nilai karakter sudah terintegrasi pada setiap pokok bahasan dari mata pelajaran matematika. Nilai-nilai karakter yang dicantumkan antara lain Religius, Kesantunan, Tanggung jawab dan Kedisiplinan. Sedangkan pada tahap pelaksanaan pendidikan dalam kegiatan pembelajaran dilakukan dengan menanamkan nilai-nilai karakter dan budaya bangsa pada peserta didik, berjalannya kegiatan pembelajaran sudah mengarah pada karakter namun belum sesuai dengan RPP yang dibuat sehingga pengimplementasian pendidikan karakter dalam mata pelajaran matematika berjalan seadanya dan belum maksimal. Dan penilaian dalam kurikulum 2013 merupakan penilaian autentik yaitu penilaian yang mencakup tiga ranah yaitu pengetahuan, sikap dan keterampilan. Terdapat 4 lembar penilaian terhadap sikap peserta didik yaitu lembar penilaian sikap jurnal, penilaian sikapobservasi, penilaian sikap-diri, penilaian sikapteman sebaya. Akan tetapi guru merasa lembar penilaian yang diberikan terlalu banyak aspek yang dinilai sehingga akan menghabiskan waktu dalam melakukan penilaian. Guru mensiasati penilaian dengan mencatat segala pelanggaran maupun perbuatan positif peserta didik pada buku pribadi mereka masingmasing.

\section{Pengaruh Program}

Pengintegrasian nilai - nilai karakter dalam pembelajaran matematika memberikan pengaruh positif dan pengaruh negatif. Pengaruh positif yang ditimbulkan yaitu mengubah perilaku peserta didik menjadi lebih bertanggung jawab dalam penyelesaian tugas, peduli terhadap lingkungan dengan pembiasaan memelihara kebersihan lingkungan kelas, toleransi, disiplin, dan cinta damai dan prestasinya pun mengalami peningkatan walaupun tidak signifikan tetapi ada sedikit perubahan menjadi lebih baik.

Disamping pengaruh positif adapun pengaruh negatif yang ditimbulkan dalam pengimplementasian program penguatan pendidikan karakter yaitu menambah beban kerja guru dalam hal penilaian sikap

Faktor-faktor yang Mempengaruhi Program

Faktor-faktor yang mempengaruhi pelaksanaan program penguatan pendidikan karakter yang terintegrasi dalam mata 
pelajaran matematika dapat ditinjau dari beberapa segi. Penulis menemukan empat faktor dalam pelaksanaan program di SMP Negeri 2 Waingapu yaitu sarana dan prasarana yang kurang memadai, akses informasi yang kurang sehingga mengakibatkan pemahaman guru tentang konsep pendidikan karakter yang masih belum menyeluruh, tenaga pendidik dan peserta didik.

\section{Pembahasan}

\section{Implementasi Program}

Pelaksanaan pembelajaran yang baik memerlukan perencanaan program yang baik pula. Itu berarti keberhasilan belajar peserta didik-siswi sangat ditentukan oleh perencanaan yang dibuat guru (Asroha, 2010: 1). Implementasi pendidikan karakter dalam mata pelajaran matematika di mulai dari tahap perencanaan, pelaksanaan hingga evaluasi. Pada tahap 1 perencanaan pembelajaran dilaksanakan oleh guru secara terprogram dan terencana dari awal. Pada tahap perencanaan pembelajaran ini guru mempersiapkan segala administrasi baik dalam bentuk prota, prosem, silabus, RPP, dan juga media pendukung lainnya. Perencanaan pembelajaran yang dibuat oleh guru di SMP negeri 2 waingapu belum dilakukan secara mandiri dikarenakan kurangnya pengetahuan guru tentang kurikulum 2013 maupun konsep pendidikan karakter itu sendiri. Hal ini menyebabkan guru belum dapat memilih nilai-nilai karakter yang sesuai dengan mata pelajaran yang diampunya, guru belum memiliki kompetensi yang memadai untuk mengintegrasikan nilai-niai karakter dan guru belum dapat menjadi teladan atas nilai-nilai karakter yang dipilihnya.

Penelitian ini sejalan dengan penelitian yang dilakukan oleh Sardjijo dan Hapzi (2017) dengan judul Integrating Character Building into Mathematics and Science Courses in Elementary School. Penelitian ini dimaksudkan untuk meninjau usaha guru dalam memilih dan menentukan jenis karakter yang diintegrasikan ke dalam kursus sekolah khusus: Matematika dan sains. Hasilnya menunjukkan bahwa menentukan jenis karakter ditemukan mudah bagi guru untuk diterapkan dalam RPP; Tapi dalam implementasinya, bahwa sebagian besar guru tidak mengerti tentang jenis karakter yang tertulis dalam RPP ditekankan dalam proses pembelajaran.

Pelaksanaan program penguatan pendidikan karakter yang terintegrasi dalam mata pelajaran matematika di SMP Negeri 2 Waingapu, dalam pelaksanaan Kegiatan pembelajaran ditahapan ini dimulai dari kegiatan pendahuluan, inti, dan penutup dilaksanakan agar peserta didik mempraktikkan nilai-nilai karakter yang ditargetkan. Dalam pelaksanaan pembelajaran ini guru harus merancang langkah-langkah pembelajaran yang memfasilitasi peserta didik aktif dalam proses mulai dari pendahuluan, inti, hingga penutup. Dalam pelaksanaan pembelajaran guru sudah cukup memahami keberagaman peserta didik. Hal ini terlihat dari sikap dan perhatian guru selama pembelajaran berlangsung. Secara umum, guru tidak segan menanyakan kepada peserta didik tentang halhal yang belum bisa dipahami terkait dengan materi yang disampaikan. Disamping itu, kedekatan peserta didik terhadap guru cukup baik. Kegiatan menutup pelajaran terdiri atas melakukan refleksi atau membuat rangkuman dengan melibatkan peserta didik dan melaksanakan tindak lanjut dengan memberikan arahan kegiatan, atau tugas yang menjadi pekerjaan rumah peserta didik.

Evaluasi atau penilaian merupakan bagian yang sangat penting dalam proses pendidikan. Dalam pendidikan karakter, penilaian harus dilakukan dengan baik dan benar. Penilaian tidak hanya menyangkut pencapaian kognitif peserta didik, tetapi juga pencapaian afektif dan psikomorotiknya. Penilaian karakter lebih mementingkan pencapaian afektif dan psikomotorik peserta didik dibandingkan pencapaian kognitifnya. 


\section{Pengaruh Program}

Program penguatan pendidikan karakter membawa pengaruh yang positif dalam prestasi maupun perilaku peserta didik di sekolah. Dengan pendidikan karakter tersebut peserta didik akan lebih berprestasi. Hal ini sesuai dengan pendapat Raka, Mulyana, Markam, Semiawan, Hasan, Bastaman, dan Nurachman (2011: 204) "pendidikan karakter yang dilakukan dengan benar akan meningkatkan prestasi akademik peserta didik". Peserta didik yang berprestasi dan memiliki karakter yang baik merupakan tujuan pendidikan nasional. Hal tersebut tertuang dalam Undang-Undang Sistem Pendidikan Nasional No. 20 tahun 2003 pasal 3 yang berbunyi: Pendidikan nasional berfungsi mengembangkan kemampuan dan membentuk watak serta peradaban bangsa yang bermartabat dalam rangka mencerdaskan kehidupan bangsa, bertujuan untuk berkembangnya potensi peserta didik agar menjadi manusia yang beriman dan bertakwa kepada tuhan Yang Maha Esa, berakhlak mulia, serta sehat, berilmu, cakap, kreatif, mandiri dan menjadi warga negara yang demokratis dan bertanggung jawab. Tujuan pendidikan nasional di atas hanya bisa dicapai dengan menerapkan pendidikan karakter terhadap peserta didik.

Keberhasilan pendidikan karakter yang diterapkan oleh guru terhadap peserta didik di ukur dari perubahan sikap peserta didik dari yang tidak baik menuju perilaku yang baik. Perlunya pendidikan karakter ditanamkan kepada peserta didik juga disampaikan oleh Berkowitz dalam Asmani (2011: 44) sekolahsekolah yang menerapkan pendidikan karakter, terjadi peningkatan motivasi peserta didik dalam meraih prestasi akademik. Hal ini berarti, dengan termotivasinya peserta didik dalam meraih prestasi akan mengakibatkan peserta didik akan belajar dengan rajin yang nantinya prestasi belajar peserta didik akan meningkat atau bertambah bagus.
Sebagaimana yang telah diungkapkan oleh para tersebut bahwa pendidikan karakter ditanamkan oleh guru kepada peserta didik akan membuat peserta didik memiliki karakter yang baik, antara lain karakter religius, jujur, disiplin, santun, percaya diri, peduli, berpikir kritis, kerjasama, kreatif dan bertanggungjawab. Karakter inilah yang membuat prestasi belajar peserta didik meningkat.

Prestasi belajar peserta didik dapat diukur dengan melakukan penilaian. Penilaian berfungsi untuk mengukur sejauh mana pemahaman peserta didik terhadap penguasaan bahan ajar, untuk mengukur keberhasilan guru dalam menyampaikan bahan ajar yang keterkaitannya dengan metode dan media yang digunakan oleh guru. Penilaian yang dilakukan dalam Kurikulum 2013 adalah penilaian autentik. Penilaian autentik adalah penilaian mencangkup tiga ranah yaitu pengetahuan, sikap dan keterampilan, penilaian dilakukan secara objektif dan menyeluruh pada keterampilan-keterampilan yang dilakukan oleh peserta didik. Namun penilaian pada ranah sikap masih dianggap sulit dalam melakukan penilaiannya. Padahal penilaian sikap merupakan bagian dari penilaian autentik. Dari penilaian sikap harus diketahui sikap peserta didik seperti apa, sebagai titik tolak untuk melakukan tindak lanjut terhadap peserta didik tersebut. Penilaian hasil belajar sikap kurang mendapat perhatian dari guru. Para guru lebih banyak menilai ranah pengetahuan semata-mata (Sudjana, 2006: 29). Dalam Kurikulum 2013 cara menilai sikap dapat dilakukan melalui observasi, penilaian diri, penilaian antar teman dan jurnal. Proses penilaian afektif dibutuhkan instrumen penilaian. Instrumen penilaian adalah alat bantu dalam melakukan penilaian agar memudahkan dalam melakukan penilaian. Penilaian sikap malalui observasi harus dibutuhkan instrumen penilaian berupa rubrik. Pembuatan instrumen penilaian sikap berupa 
rubrik, guru masih mengalami kesulitan dalam pembuatan instrumen penilaian sikap sehingga kurang terdapat rubrik pada ranah sikap. Penggunaan insturmen penilaian sikap umunya masih terbatas berupa catatan-catatan kecil yang dimiliki guru, tanpa ada instrumen khusus yang digunakan untuk menilai sikap peserta didik, seperti lembar observasi, lembar penilaian diri atau pun lembar penilaian antar teman. Meskipun ada itu masih terbatas format tabel yang harus diisi oleh guru, tanpa ada kriteria tertentu dalam format tabel tersebut.

\section{Faktor-faktor yang Mempengaruhi Program}

Implementasi pendidikan karakter dalam pembelajaran di SMP Negeri 2 Waingapu terdapat beberapa kendala yaitu: sarana dan prasarana pendidikan kurang memadai yaitu bangunan sekolah yang masih seadanya, alat alat pendidikan yang kurang lengkap seperti bangku dan meja peserta didik yang rusak ringan, buku-buku sebagai sumber belajar yang masih minim, dan media pendidikan kurang lengkap. Selain itu, kurangnya tenaga pendidik yang profesional menjadikan pemahaman guru tentang konsep pendidikan karakter yang masih belum menyeluruh sehingga guru belum dapat memilih nilai-nilai karakter yang sesuai dengan mata pelajaran yang diampunya.dan peserta didik.

Temuan penelitian ini sejalan dengan Sardjijo dan Hapzi (2017) dengan judul Integrating Character Building into Mathematics and Science Courses in Elementary School. Penelitian ini dimaksudkan untuk meninjau usaha guru dalam memilih dan menentukan jenis karakter yang diintegrasikan ke dalam mata pelajaran sekolah khusus: Matematika dan sains. Hasilnya menunjukkan bahwa menentukan jenis karakter ditemukan mudah bagi guru untuk diterapkan dalam RPP; tapi dalam implementasinya, katanya bahwa sebagian besar guru tidak mengerti tentang jenis karakter yang tertulis dalam RPP ditekankan dalam proses pembelajaran.

Minimnya pengetahuan guru konsep pendidikan karakter disebabkan karena keterbatasan akses informasi dan pelatihan masih sangat terbatas untuk diikuti guru. Pelatihan tidak melibatkan semua guru tetapi hanya perwakilan. Karena minimnya informasi dan pengetahuan guru sehingga program berjalan seadanya, tanpa diimbangi dengan pengetahuan guru. selain pengetahuan guru yang minim, perbedaan kompetensi peserta didik juga menjadi faktor penghambat dalam pengimplementasian pendidikan karakter dalam mata pelajaran matematika. Perbedaan kompetensi menjadikan peserta didik kurang paham akan pesan pendidikan karakter yang disampaikan sehingga dalam proses belajar mengajar masih terdapat peserta didik yang berperilaku tidak sesuai harapan.

\section{SIMPULAN DAN SARAN \\ Simpulan}

Berdasarkan analisis hasil penelitian dan pembahasan terhadap program penguatan pendidikan karakter di SMP Negeri 2 Waingapu dapat diambil kesimpulan sebagai berikut:

1. Implementasi pendidikan karakter yang terintegrasi dalam mata pelajaran matematika di SMP Negeri 2 Waingapu dimulai dari tahap perencanaan, pelaksanaan dan evaluasi. Peran guru dalam perencanaan, pelaksaan dan evaluasi yang mengimplementasi pendidikan karakter belum dilakukan secara optimal sehingga program berjalan seadanya

2. Pengaruh pendidikan karakter yang terintegrasi dalam mata pelajaran matematika membawa pengaruh positif baik bagi perserta didik baik dari segi prestasi maupun perilaku peserta didik dan pengaruh negatif bagi guru karena dengan pengimplementasian program penguatan pendidikan karakter beban kerja guru 
bertambah khususnya dalam hal penilaian sikap

3. Faktor-faktor yang menghambat pengimplementasian pendidikan karakter yang terintegrasi dalam mata pelajaran matematika yaitu sarana dan prasarana yang terbatas, kurangnya tenaga pendidik yang profesional, akses informasi yang terbatas dan sikap dan mentalitasi peserta didik itu sendiri.

\section{Saran}

Berdasarkan kesimpulan-kesimpulan diatas maka dirumuskan beberapa masukan bagi pihak-pihak yang berkepentingan.

1. Bagi guru khususnya guru matematika untuk lebih kreatif dan mandiri dalam menyusun rencana pelaksanaan pembelajaran bernilai-nilai karakter dan betul-betul diterapkan pada saat proses belajar mengajar berlangsung sesuai dengan materi yang akan ajarkan, sehingga tujuan pembelajaran dapat tercapai dan peserta didik termotivasi dalam belajar dikelas. Guru lebih mendalam mengikuti seminar, pelatihan, penataran, dan workshop guna meningkatkan pengalaman dan pengetahuan yang terjadi di lapangan. Pendidik lebih memperhatikan, membimbing, membina dan memberikan contoh yang positif kepada peserta didik. Pendidik melengkapi administrasi pembelajaran dengan kualitas yang lebih baik dan pendidik juga harus memberikan teladan yang baik pada peserta didik.

2. Kepala Sekolah dapat menjaga keberlangsungan program penguatan pendidikan karakter yang ada di SMP Negeri 2 Waingapu dan diharapkan kepala sekolah juga membimbing, mengarahkan guru untuk meningkatkan kemampuan dan kesadaran untuk menjadi teladan dan ujung tombak dalam melaksanakan program pembelajaran pendidikan karakter.

3. Pengawas Sekolah diharapkan sering melakukan pelatihan ataupun supervisi terhadap guru mengenai perangkat pembelajaran dan proses belajar mengajar yang mengintegrasikan pendidikan karakter, karena dengan pengetahuan dan kemampuan guru yang baik akan meningkatkan hasil pembelajaran peserta didik dan pembentukan sikap sesuai dengan tujuan pendidikan karakter.

4. Dinas Pendidikan agar tetap mengadakan pelatihan terutama pada saat penyusunan silabus dan rencana pelaksanaan pembelajaran. Peran MGMP perlu dioptimalkan dalam mengkaji perancangan dan pelaksanaan pembelajaran dikelas karena guru merupakan salah satu faktor penentu dalam keberhasilan penerapan pendidikan karakter di sekolah sehingga diperlukan pemahaman yang baik tentang konsep pendidikan karakter, mengadakan seminar, pelatihan, penataran, dan workshop untuk membantu pendidik (guru) dalam melaksanakan pengembangan pendidikan karakter. Diharapkan lebih baik lagi dalam membina karakter peserta didik di sekolah sesuai dengan karakter bangsa Indonesia. Pihak sekolah juga harus selalu mengadakan evaluasi demi ketercapaian pengembangan pendidikan karakter yang lebih baik.

\section{DAFTAR PUSTAKA}

Albertus, Doni Koesoema. (2010). Pendidikan Karakter Strategi Mendidik Anak di Zaman Global. Jakarta: PT.Grasindo.

Arikunto, S. (2012). Prosedur Penelitian. Suatu Pendekatan Praktik. Edisi Revisi 6. Jakarta: Rineka Cipta

Arikunto, S. \& Jabar, C.S.A., (2012). Evaluasi Program Pendidikan. Jakarta: Bumi Aksara.

Asmani, Jamal. (2011). Buku Panduan Internalisasi Pendidikan Karakter Sekolah. Jogjakarta: Diva Press. 
Evaluasi Program PPK Yang Terintegrasi Dalam Mata Pelajaran Matematika ... | Elsy S. H. Taunu, dkk

Asroha, Hanun. (2010). Perencanaan

Pembelajaran (Surabaya: Kopertis IV-

Pemprov Jatim).

Darmayanti, S. E. \& Udik Budi Wibowo.

(2014). Evaluasi Program Pendidikan

Karakter Di Sekolah Dasar Kabupaten

Kulon Progo. Jurnal Prima Edukasia

Vol 2 (2) hal: 223-234.

Ekowati, D.W., Setyaningrum, R.W.,

Husamah. (2012). Model Pembelajaran

Pendidikan Karakter pada Pembelaran

Tematik di SD Muhammadiyah 9 Kota

Malang. Jurnal Humanity, Vol 8 No 1, hal: 117-127.

Kemendikbud. (2017). Modul Konsep dan

Pedoman Penguatan Pendidikan

Karakter Tingkat Sekolah Dasar dan

Menengah Pertama. Jakarta:

Depdikbud.

Listyarti, Retno. (2012). Pendidikan Karakter dalam Metode Aktif, Inovatif dan

Kreatif. Jakarta: Esensi, Divisi Penerbit Erlangga.

Mulyasa, H.E. (2013). Manajemen Pendidikan Karakter. Jakarta: PT Bumi Aksara.

Muslich, Masnur. (2011). Pendidikan Karakter Menjawab Tantangan Krisis Multidimensional. Jakarta: PT Bumi Aksara.

Nur Aisyah, Emosda, Suratno. (2015). Implementasi Pendidikan Karakter Di SDIT Nurul Ilmi Kota Jambi. Jurnal Tekno-Pedagogi, Vol 5 No 1, hal: 5063
Pusat Bahasa Departemen Pendidikan Nasional. (2002). Kamus Besar Bahasa Indonesia. Jakarta: Balai Pustaka.

Raka, Gede.,Mulyana, Y., Markam, S.S., Semiawan, C.R., Hasan, S.H., Bastaman, H.D., dan Nurachman, N. (2011). Pendidikan Karakter di Sekolah; dari Gagasan ke Tindakan. Jakarta: Elek Media Komputindo

Sardjijo dan Hapzi Ali. (2017). Integrating Character Building into Mathematics and Science Courses in Elementary School. International Journal Of Environmental \& Science Education 2017, Vol. 12, No. 6, 1547-1552.

Sudjana, Nana. (2006). Penilaian Hasil Proses Belajar Mengajar. Bandung: Remaja Rosdakarya

Sukmadinata, N.S., (2004). Kurikulum dan Pembelajaran Kompetensi. Bandung: Yayasan Kusuma Karya.

Wirawan. (2011). Wirawan. 2011. Evaluasi Teori Model Standar Aplikasi dan Profesi, Contoh Aplikasi Evaluasi Program : Pengembangan Sumber Daya Manusia Program Nasional Pemberdayaan Masyarakat (PNPM) Mandiri Pedesaan, Kurikulum, Perpustakaan, dan Buku Tes. Jakarta: Raja Grafindo Persada

Zubaedi. (2011). Pendidikan Karakter: konsep dan aplikasinya Dalam Lembaga Pendidikan. Jakarta: Kencana. 